\title{
SCHIEFFER, Rudolf, Die Streitschriften Hinkmars von Reims und Hinkmars von Laon, 869-871
}

\section{Philippe Depreux}

\section{OpenEdition}

\section{Journals}

Édition électronique

URL : http://journals.openedition.org/ifha/945

DOI : $10.4000 /$ ifha. 945

ISSN : 2198-8943

\section{Éditeur}

IFRA - Institut franco-allemand (sciences historiques et sociales)

\section{Référence électronique}

Philippe Depreux, «SCHIEFFER, Rudolf, Die Streitschriften Hinkmars von Reims und Hinkmars von Laon 869-871 », Revue de I'IFHA [En ligne], Date de recension, mis en ligne le 01 janvier 2004, consulté le 22 septembre 2020. URL : http://journals.openedition.org/ifha/945 ; DOI : https://doi.org/10.4000/ifha. 945

Ce document a été généré automatiquement le 22 septembre 2020.

(C)IFHA 


\title{
SCHIEFFER, Rudolf, Die Streitschriften Hinkmars von Reims und Hinkmars von Laon, 869-871
}

\author{
Philippe Depreux
}

1 La publication des traités rédigés par l'archevêque de Reims, Hincmar, et son homonyme, l'évêque de Laon, à la fois son neveu et son suffragant, complète l'édition, par Wilfried Hartmann, des actes des synodes tenus dans les années 860-874, dont certains furent le théâtre de l'affrontement entre ces deux hommes, où les mobiles canoniques se mâtinent de raisons d'ordre plus psychologique ; l'assemblée de Douzy (871) fut d'ailleurs exclusivement consacrée à l'examen des charges pesant contre Hincmar de Laon. Cette publication n'offre qu'un éclairage partiel sur les relations entre l'oncle et le neveu (on attend l'achèvement par R.S. de l'édition des lettres d'Hincmar de Reims), mais il est d'autant plus précieux qu'il permet d'étudier la manière dont ces deux prélats affûtaient leurs arguments en constituant des dossiers canoniques. Ce volume est dominé par la Collection en 55 chapitres qu'Hincmar de Reims soumit au roi Charles le Chauve et aux Pères du concile d'Attigny, en 870 (p. 99-361), conçue comme une réponse aux griefs exposés par Hincmar de Laon lors de l'assemblée de Gondreville (869), dans son Pittaciolus ou «petite notice » (p. 57-97), dont l'édition est précédée d'un ensemble de compilations canoniques préparatoires à la rédaction de ce mémorandum (p. 1-55). La Collection en 55 chapitres s'impose non seulement par son volume et son argumentation, mais aussi par la réception que lui réservèrent certains canonistes et auteurs médiévaux, tels Gerbert de Reims, Bernard de Hildesheim, Yves de Chartres ou Nicolas de Cues (cf. p. 121-129). Ce volume est complété par la défense rédigée par Hincmar de Laon : le libelle désigné par Hincmar de Reims sous le nom de Rotula prolixa, rédigé entre août et novembre 870 (p. 363-408), et une collection canonique compilée au cours du premier semestre de l'année 871 (Collectio ex epistolis Romanorum pontificum, p. 409-419). L'édition de ces traités constitue une importante contribution à l'étude du droit canonique et de l'influence exercée par le Pseudo-Isidore, dont l'archevêque de Reims contestait les idées en se battant avec les mêmes armes, c'est-à-dire en citant des autorités patristiques, et non 
en contestant l'authenticité de cette collection. Divers indices font de cette édition un réel instrument de travail : un index des citations scripturaires et patristiques, un index onomastique et, surtout, un index rerum de plus de 120 pages.

Philippe DEPREUX (MHFA) 